\title{
Psychological distress in health sciences college students and its relationship with academic engagement*
}

\author{
MAL-ESTAR PSICOLÓGICO EM ESTUDANTES UNIVERSITÁRIOS DE CIÊNCIAS DA \\ SAÚDE E SUA RELAÇÃO COM O ENGAGEMENT ACADÊMICO
}

\section{MALESTAR PSICOLÓGICO EN ESTUDIANTES UNIVERSITARIOS DE CIENCIAS DE LA SALUD Y SU RELACIÓN CON ENGAGEMENT ACADÉMICO}

\section{Cristina Liébana-Presa', $\mathbf{M}^{\mathrm{a}}$ Elena Fernández-Martínez², África Ruiz Gándara ${ }^{3}$, $\mathbf{M}^{\mathrm{a}}$ Carmen Muñoz-Villanueva ${ }^{4}$, Ana María Vázquez-Casares ${ }^{5}$, M $^{\mathrm{a}}$ Aurora Rodríguez-Borrego ${ }^{6}$}

\begin{abstract}
Objective: To determine the prevalence of psychological distress and its relationship with academic engagement (absorption, dedication and vigor), sex and degree among students from four public universities. Method: A non-experimental, comparative correlational, quantitative investigation without intervention. Study population: 1840 nursing and physical therapy students. The data collection tool used was a questionnaire. Results: A $32.2 \%$ prevalence of psychological distress was found in the subjects; a correlation between vigor and psychological distress was found for all of the subjects and also for women. High absorption and dedication scores and low psychological distress scores predicted higher vigor scores. Conclusion: The risk of psychological distress is high, especially for women. Women seem to have a higher level of psychological distress than men. Vigor, energy and mental resilience positively influence psychological distress and can be a vehicle for better results during the learning and studying process.
\end{abstract}

\section{RESUMO}

Objetivo: Determinar a prevalência do mal-estar psicológico e a sua relação com o engagement acadêmico (absorção, dedicação e vigor) e as variáveis sexo e formação profissional em estudantes de quatro universidades públicas. Método: Investigação quantitativa sem intervenção, estudo não experimental e correlacional comparativo. A amostra foi constituída por 1.840 alunos de Enfermagem e Fisioterapia e o instrumento de coleta de dados foi o questionário. Resultados: A prevalência do mal-estar psicológico foi encontrada em $32,2 \%$ dos indivíduos; foram encontradas correlações entre vigor e mal-estar psicológico para o conjunto dos sujeitos, principalmente para o grupo das mulheres. A existência de escores elevados para dedicação e absorção, e baixos para mal-estar psicológico é preditora de pontuações mais elevadas em vigor. Conclusão: 0 risco de mal-estar psicológico é elevado, especialmente nas mulheres. Estas se percebem com maior mal-estar psicológico que os homens. O vigor, a energia e a resistência, aplicados na relação com os estudos influenciam positivamente o mal-estar psicológico e podem ser um veículo para melhores resultados de aprendizagem

DESCRITORES
Engagement
Mal-estar psicológico
Enfermagem
Fisioterapia
Estudantes de graduação

\section{RESUMEN}

Objetivo: Determinar la prevalencia del malestar psicológico y su relación con el engagement académico (absorción, dedicación y vigor) y con variables sexo y titulación, de los estudiantes de cuatro universidades públicas. Método: Estudio comparativo correlacional, investigación cuantitativa sin intervención, no experimental. Población 1840 estudiantes de Enfermería y Fisioterapia. La herramienta de recogida de datos fue el cuestionario. Resultados: Prevalencia de malestar psicológico en el $32.2 \%$ de los sujetos; se hallaron correlaciones entre vigor y malestar psicológico para el conjunto de sujetos y para el grupo de las mujeres. Las puntuaciones altas en absorción y dedicación y bajas en malestar psicológico, predicen valoraciones más altas en vigor. Conclusión: El riesgo de malestar psicológico es alto, especialmente para las mujeres. Éstas se perciben con mayor malestar psicológico que los hombres. El vigor, energía y resistencia con los estudios, influye positivamente sobre el malestar psicológico y puede ser un vehículo para unos mejores resultados del aprendizaje.

\author{
DESCRIPTORES \\ Engagement \\ Malestar psicológico \\ Enfermería \\ Fisioterapia \\ Estudiante de pregrado
}

\footnotetext{
* Taken from the thesis "Salud emocional en estudiantes universitarios de Enfermería y Fisioterapia de Castilla y León", University of Cordoba, 2011. ${ }^{2}$ Professor, Department of Nursing and Physical Therapy, University of Leon, Ponferrada, Leon, Spain. ${ }^{3}$ Full Professor, Department of Nursing and Physical Therapy, University of Leon, Ponferrada, Leon, Spain. ${ }^{4}$ Research Training and Teaching Staff, Department of Statistics, Econometrics, Operative Research, Business Organization and Applied Economics, University of Cordoba, Cordoba, Spain. ${ }^{5}$ Area Director of Methodology and Statistics, Maimonides Institute of Biomedical Research of Cordoba, Cordoba, Spain. ${ }^{6}$ Professor, Department of Nursing and Physical Therapy, University of Leon, Ponferrada, Leon, Spain. 7 Full Professor, Department of Nursing, University of Cordoba, Cordoba, Spain.
}

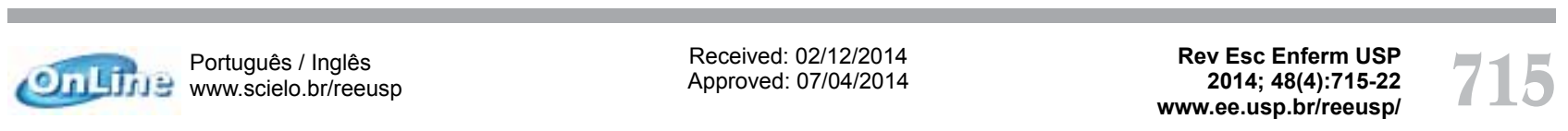




\section{INTRODUCTION}

Health is understood to be not just the absence of illness; its definition implies a comprehensive and integrative understanding of people that includes many interrelated social, psychological and physical factors ${ }^{(1)}$. Likewise, the World Health Organization proposes that the promotion of mental health and the prevention of mental disorders can help to maintain or improve health, have a positive effect on quality of life and can be economically beneficial(2) $^{(2)}$ The availability of mental health records and information systems is necessary for conducting research and studies on mental health promotion and prevention in college students, and institutions of higher education have made a commitment to this process for some time ${ }^{(3)}$.

During the academic year, nursing and physical therapy students face many risk situations that can alter their academic achievement and cause them psychological distress $^{(4-5)}$. The most common sources of this distress are, among others, their workload and problems associated with their studies, fear of unknown situations and difficulties during their clinical practices ${ }^{(6)}$. In addition, students must embody certain personal factors (assertiveness, being able to say no, confrontation, self-esteem and social relationships) that involve multiple and significant adaptations that they must adequately and immediately make during their training period ${ }^{(7-8)}$. If these risks are not recognized, they can negatively affect the student's health ${ }^{(9-12)}$, learning or academic self-efficacy ${ }^{(13)}$, satisfaction with their studies and, consequently, the quality of the attention they offer patients during clinical practice.

It is essential to identify students who are at a higher risk of suffering from health problems. A reliable and valid instrument for measuring psychological distress before any intervention is considered is the 12 -item version of the General Health Questionnaire ${ }^{(14)}$ (GHQ-12). The GHQ questionnaire centers on two types of problems: the selfperceived difficulty developing healthy functioning and the occurrence of stressful events. The GHQ is an instrument that screens the population in question to detect the prevalence of probable cases of psychiatric morbidity or psychological condition by exploring the subject's usual state during the month prior to the screening as a reflection of their overall usual state.

In Spain, studies using the GHQ-12 to examine the psychological distress of nursing and physical therapy students are rare. In a few instances, distress has been evaluated by measuring burnout syndrome ${ }^{(6,15)}$. Academic engagement is a construct that is considered to be the opposite of burnout syndrome ${ }^{(16)}$, and examining it can indicate whether academic engagement positively influences the student's psychological distress. As opposed to those who suffer from burnout syndrome, engaged students feel connected to their tasks. Instead of considering these tasks stressful, they perceive them as challenges. They are strongly and effectively connected with the activities that they engage in, and they are seen as capable of meeting the demands that they face ${ }^{(17)}$. In general terms, it can be said that academic engagement refers to bonding, involvement, passion, enthusiasm, effort and energy related to one's work. To measure this variable in college students, the Utretch Work Engagement Scale for Students (UWESS) was selected. This 17 -item questionnaire was originally created for a sample of workers (UWES) and is used to measure three construct dimensions ${ }^{(18)}$ : vigor, dedication and absorption. Vigor measures energy and mental resilience during the learning process (I can continue studying during long periods of time), i.e., the student's desire to invest effort, time and persistence in his or her studies. Dedication, the second dimension the authors described, reflects the student's study-related characteristics, such as enthusiasm, pride, inspiration and challenge (I am proud of pursuing this career). Finally, absorption (time 'flies by' when I carry out my tasks) indicates a pleasant state of total concentration on the work. With absorption, an individual is incapable of being separated from his or her efforts even after having spent a great deal of time working on them.

The research on academic commitment among college students in Spain is not very extensive given the relative newness of the concept. Nevertheless, the positive influence of engagement on various academic and personal aspects of a student's character, including psychological well-being ${ }^{(19-20)}$, academic achievement and satisfaction with his or her studies ${ }^{(21)}$, seems clear. At the same time, research indicates the need to promote the development of students' emotional abilities to alleviate their academic stresses and to stimulate positive attitudes toward their studies ${ }^{(22-23)}$.

For these reasons, the aims of the present study are to determine the prevalence of psychological distress using the GHQ-12, to describe the level of academic engagement measured with UWES-S and to analyze the relationship between these constructs and personal variables, including sex and degree, in nursing and physical therapy students enrolled in public universities in Castilla and Leon (Spain). When psychological distress was identified, this work aimed to present, promote and develop strategies that improve psychological well-being and to provide students with resources to help them confront these academic demands and to successfully earn their college degree.

\section{METHOD}

\section{Design}

A non-experimental comparative correlation study that uses quantitative research methods without intervention. A questionnaire was used for data collection.

\section{Subjects and study environment}

The study population was composed of 1840 nursing and physical therapy students enrolled in 2009/2010

\section{Rev Esc Enferm USP \\ 2014; 48(4):715-22 \\ www.ee.usp.br/reeusp/}

Psychological distress in health sciences college students and its relationship with academic engagement Liébana-Presa C, Fernández-Martínez ME, Gándara ÁR, Muñoz-Villanueva MC Vázquez-Casares AM, Rodríguez-Borrego MA 
academic classes in the public universities of Castilla and Leon, Spain. In the four public universities (Burgos, Leon, Salamanca and Valladolid), 1390 students (75.5\%) studied nursing and 450 (24.5\%) studied physical therapy. The entire population was included to achieve a greater number of participants, to avoid the possibility of sample losses and to show utmost respect for students' privacy.

\section{Instruments}

A self-completed document collected sociodemographic information, including sex, age, course, degree and the university where the subjects were carrying out their studies.

\section{GHQ-12}

The 12-item version of the General Health Questionnaire (GHQ-12) was validated by the same authors ${ }^{(14)}$. This scale is used as an indicator of psychological distress. Each item of the GHQ describes a symptom and has four possible answers: the two answers that indicate the absence of the symptom are assigned a score of 0 , and the two that indicate the presence of symptoms are assigned a score of 1 . The score for the entire scale can range from 0 to 12 . This scale infers that the higher the total score is, the higher the psychological distress will be.

\section{UWES-S}

The Utretch Work Engagement Scale for Students (UWES-S) is an academic engagement questionnaire that was adapted for and validated with students from different countries ${ }^{(18)}$. It is a 17 -item scale used to measure the three dimensions of engagement: vigor ( 6 items), dedication ( 5 items) and absorption (6 items). The participants' answers are quantified according to a Likert-type scale, on which 0 signifies complete disagreement and 6 indicates complete agreement with the item's statement. High scores on these dimensions reflect high levels of engagement in studies.

\section{Procedure}

The questionnaires were administered in classrooms during academic class hours. Permission to collect data was requested from the administrators and professors at the corresponding centers. The participants were informed of the guidelines for completing the questionnaires and were given 20 minutes to complete the questionnaire. Oral and written informed consent explaining the voluntary nature and the purpose of the study was given to all participants. Similarly, the absolute confidentiality of all information was emphasized.

\section{Data analysis}

The statistical analysis of the data was descriptive, analytic and correlational. After using the Shapiro-Wilk tests to verify that the data did not follow a normal distribution for quantitative variables, non-parametric tests
(Mann-Whitney U-test) were conducted to compare the averages between degree and sex groups. To evaluate the associations between quantitative variables, nonparametric correlations were performed, and Spearman's Rho coefficients were obtained. To determine the psychometric indicators that the instrument measured, basic descriptive statistics and reliability coefficients (Cronbach's alpha) were analyzed. Using multiple linear regression, a model with one dependent and several independent variables was developed.

The database and statistical analyses were carried out using the SPSS 19.0 (Statistical Package for the Social Sciences) software.

\section{Limitations}

The results obtained did not allow us to draw any conclusions about causality among the variables studied. To infer causality, it would be necessary to develop longitudinal or experimental studies to more fully study this question.

The subjects studied were not representative of the college population because they only came from two health sciences branches, nursing and physical therapy.

A sex-related bias also exists because the student population was not homogeneous with regard to sex; consequently, the results and conclusions regarding sex differences should be considered with caution.

\section{Ethical considerations}

The study protocol and instruments were presented and approved by the Ethics Committee Executive Board of the University of Leon.

The proposed research respects the fundamental principles of the Statement of Helsinki, the Council of Europe relating to human rights and biomedicine, UNESCO's Universal declaration on the human genome and human rights and the Council of Oviedo relating to human rights and biomedicine.

The questionnaires were accompanied by an informational pamphlet and by verbal and written consent.

\section{RESULTS}

\section{Participants' sociodemographic characteristics}

A total of 1278 subjects participated (Table 1). The average age was 21.36 years, the mode was 20 years, and less than $10 \%$ were over 21 years old. The subjects analyzed were distributed into the different health sciences degrees in the following manner: 1009 students (79\%) were enrolled in nursing, and 269 (21\%) were enrolled in physical therapy. Regarding sex, there were 1062 women (83.1\%), 189 men (14.8\%), and 27 people $(2.1 \%)$ who did not correctly specify their sex. 
Table 1 - Sociodemographic characteristics

\begin{tabular}{llccc}
\hline & Public universities & Men 189 (14.8\%) & Women 1062 (83.1\%) & Total N=1278 (100\%) \\
\hline Nursing & Leon & 52 & 376 & 428 \\
N=1009 (79\%) & Salamanca & 20 & 100 & 120 \\
& Valladolid & 43 & 269 & 312 \\
& Burgos & 12 & 114 & 126 \\
Physical therapy & Leon & 35 & 105 & 140 \\
N=269 (21\%) & Salamanca & 13 & 50 & 63 \\
& Valladolid & 14 & 48 & 62 \\
\hline Unknown & & & $\mathbf{2 7 ( 2 . 1 \% )}$ \\
\hline
\end{tabular}

\section{Descriptive}

The median value of psychological distress measured with the GHQ-12 was 3.5856, and the averages obtained for the academic engagement questionnaire (UWES-S) were 26.76 for absorption, 25.81 for dedication and 26.59 for vigor (Table 2). Table 3 shows that the women had higher average scores than the men for all variables studied.

The prevalence of psychological distress in the participants was $32.2 \%$.

Table 2 - Descriptive statistics

\begin{tabular}{lcccccc}
\hline & $\mathbf{N}$ & Minimum & Maximum & Average & Standard deviation & Cronbach's Alpha \\
\hline GHQ-12 & 1274 & .00 & 12.00 & 35.856 & 290.531 & .818 \\
Absorption & 1259 & .00 & 6.00 & 32.093 & .98383 & .803 \\
Dedication & 1259 & .00 & 6.00 & 44.019 & .95273 & .793 \\
Vigor & 1259 & .00 & 6.00 & 30.815 & .97659 & .723 \\
\hline
\end{tabular}

Table 3 - Descriptive statistics by sex and degree

\begin{tabular}{|c|c|c|c|c|c|c|c|c|}
\hline & Sex and degree & Minimum & Maximum & Average & Me* & $I_{Q} R^{*}$ & $\begin{array}{l}\text { Standard } \\
\text { deviation }\end{array}$ & $\mathbf{P}(\mathbf{1})$ \\
\hline \multirow[t]{4}{*}{ GHQ-12 } & Women & .00 & 12.00 & 36.472 & 3.00 & 4.00 & 289.411 & .006 \\
\hline & Men & .00 & 12.00 & 31.436 & 2.00 & 4.00 & 296.785 & \\
\hline & Nursing & .00 & 12.00 & 36.289 & 3.00 & 4.00 & 289.122 & Not sig \\
\hline & Physical therapy & .00 & 12.00 & 34.238 & 3.00 & 4.00 & 2,95721 & \\
\hline \multirow[t]{4}{*}{ Absorption } & Women & .00 & 6.00 & 32.380 & 3.17 & 1.33 & .97930 & .009 \\
\hline & Men & .33 & 5.83 & 30.442 & 3.00 & 1.34 & 101.068 & \\
\hline & Nursing & .33 & 6.00 & 32.405 & 3.17 & 1.33 & .98529 & .018 \\
\hline & Physical therapy & .00 & 6.00 & 30.935 & 3.00 & 1.17 & .97149 & \\
\hline \multirow[t]{4}{*}{ Dedication } & Women & .00 & 6.00 & 44.274 & 4.60 & 1.20 & .95424 & .023 \\
\hline & Men & 1.60 & 6.00 & 42.556 & 4.40 & 1.40 & .96314 & \\
\hline & Nursing & .80 & 6.00 & 43.925 & 4.60 & 1.20 & .94865 & Not sig. \\
\hline & Physical therapy & .00 & 6.00 & 44.371 & 4.60 & 1.20 & .96877 & \\
\hline \multirow[t]{4}{*}{ Vigor } & Women & .00 & 5.83 & 30.896 & 3.00 & 1.33 & .96449 & Not sig. \\
\hline & Men & .00 & 6.00 & 30.129 & 3.00 & 1.50 & 105.132 & \\
\hline & Nursing & .00 & 5.83 & 30.739 & 3.00 & 1.50 & .98416 & Not sig. \\
\hline & Physical therapy & .00 & 6.00 & 31.096 & 3.17 & 1.33 & .94922 & \\
\hline
\end{tabular}

${ }^{*}$ Data are indicated as medians (Me) and interquartile ranges (IQR). (1)Level of statistical significance obtained using the U-test and the Mann-Whitney test.

\section{Correlations}

No statistically significant correlations regarding the subjects' age were found.

Table 4 shows the relationship between the different dimensions of engagement in studies and psychological distress. The statistically significant correlations in all participants (overall) were negative and very weak with regard to the relationship between vigor and psychological distress (rho=-.088, $\mathrm{p}<0.001$ ). This means that students who scored lower in vigor obtained higher scores in psychological distress and vice versa. In addition, vigor was also significantly correlated, but this time positively, with absorption (rho=.723, p<.001) and with dedication (rho=.542, p<.001). Thus, positive associations were also found between the variables dedication and absorption ( $r h o=.546, p<.001$ ), and the three dimensions of engagement were correlated with each other. Among the women, correlations were found to be in the same direction as among all of the participants overall (Table 4). However, in the men, psychological distress did not correlate with any of the dimensions of engagement, although they were all positively related to each other. 
Table 4 - Correlation between psychological distress and engagement overall and by sex

\begin{tabular}{|c|c|c|c|c|c|}
\hline & & & Absorption & Dedication & Vigor \\
\hline \multirow[t]{3}{*}{ 1. GHQ-12 } & Overall & Spearman's rho & .029 & -.041 & $-.088(* *)$ \\
\hline & Women & Spearman's rho & .009 & -.057 & $-.117(* *)$ \\
\hline & Men & Spearman's rho & .106 & .042 & .058 \\
\hline \multirow[t]{3}{*}{ 2. Absorption } & Overall & Spearman's rho & & $.546(* *)$ & $.723(* *)$ \\
\hline & Women & Spearman's rho & & $.535(* *)$ & $.715(* *)$ \\
\hline & Men & Spearman's rho & & $.628(* *)$ & $.804(* *)$ \\
\hline \multirow[t]{3}{*}{ 3. Dedication } & Overall & Spearman's rho & & & $.542(* *)$ \\
\hline & Women & Spearman's rho & & & $.538(* *)$ \\
\hline & Men & Spearman's rho & & & $.620(* *)$ \\
\hline
\end{tabular}

The Mann-Whitney U-test results comparing the averages between sex and degree of the psychological distress and academic engagement variables are presented in Table 3.

The average psychological distress scores were significantly different $(p<.05)$ between sexes $(3.6472$ in the women compared to 3.1436 in the men). The women scored higher than the men on this questionnaire, implying that they had a higher level of psychological distress. These results are also statistically significant $(p<.05)$ for engagement; the women scored higher on absorption ( 3.2380 in the women and 3.0442 in the men) and dedication (4.44274 in the women and 4.2556 in the men) compared with the men. For the variable absorption, statistically significant differences were found between the average scores of the degree variable (3.2405 for nursing and 3.0935 for physical therapy). The nursing students obtained higher values compared with the physical therapy students.

\section{Linear regression}

As the previous section showed, psychological distress was correlated with academic engagement and particularly with vigor. In turn, vigor was the only variable studied that was correlated with all of the others. All of the participants overall behaved similarly to the group of women for the variables mentioned; consequently, linear regression using the variable vigor was conducted for both groups.

Table 5 summarizes the results of the linear regression analysis for the dependent variable vigor. Model 3 explained $57.8 \%$ of the variance in the women. The predictor variables for this model were absorption $(b=.639 t=26,849$ and $p=.000)$, dedication $(b=.181, t=7.597$ and $p=.000)$ and psychological distress $(b=-.112 t=-5,542$ and $p=.000)$. Increased scores for absorption and dedication and decreased student-perceived psychological distress predicted higher vigor scores. Similarly, although the percentage of variance was slightly lower, the same trend occurred with the data extracted for all of the participants (men and women).

Table 5 - Linear regression for vigor

\begin{tabular}{|c|c|c|c|c|c|c|}
\hline \multirow[b]{2}{*}{ Predictor variables } & \multicolumn{3}{|c|}{ Overall linear regression } & \multicolumn{3}{|c|}{ Linear regression in women } \\
\hline & Model 1 Beta & Model 2 Beta & Model 3 Beta & Model 1 Beta & Model 2 Beta & Model 3 Beta \\
\hline Absorption & $.740^{* * *}$ & $.635^{* * *}$ & $.643 * * *$ & $.734 * * *$ & $.631 * * *$ & $.639^{* * *}$ \\
\hline Dedication & & $.193 * * *$ & $.182 * * *$ & & $.195^{* * *}$ & $.181^{* * *}$ \\
\hline GHQ-12 & & & $-.097 * * *$ & & & $-.112 * * *$ \\
\hline $\mathrm{R}$ & .740 & .757 & .763 & .734 & .753 & .761 \\
\hline R2 & .547 & .573 & .583 & .539 & .566 & .579 \\
\hline Corrected R2 & .547 & .573 & .582 & .539 & .566 & .578 \\
\hline
\end{tabular}

\section{DISCUSION}

The prevalence of psychological distress among students enrolled in a health sciences program was $32.2 \%$. This value is approximately in agreement with the results of a similar study ${ }^{(4)}$ that obtained a prevalence of $36 \%$ for the same variable in 228 students enrolled in a nursing program; that study found that psychological distress was related to the students' family, academic and personal characteristics. Research on psychological distress has developed from different perspectives. Some studies have analyzed the relationship between psychological state and academic achievement ${ }^{(10)}$. Those authors showed that nursing students as a group are at high risk for developing mental health problems. Similarly, other authors $^{(24)}$ studied personality, adjustment and psychological distress in a sample of nursing students and obtained results slightly lower than those obtained in the present study: $20.7 \%$ of the students evaluated presented high GHQ-12 scores. There are studies ${ }^{(25)}$ with prevalence values very close to those obtained in the present study: $33.6 \%$ psychological morbidity in students with other health sciences degrees. In the case of physical therapy students, the results reviewed ${ }^{(12)}$ indicate a likely psychological morbidity of $27 \%$, based on the GHQ scores. With these prevalence data and affirmation from other authors ${ }^{(7)}$, it seems clear that there is a need to more thoroughly evaluate distress levels.

The women in our study scored higher in psychological distress than the men, and they perceived a greater level of 
psychological distress compared with the men. Along these lines ${ }^{(11)}$, two studies utilizing the GHQ-12 questionnaire were developed for nursing students who attended two universities in Rome (Italy). Those studies found that the risk of psychological distress (anxiety and depression) was higher in women compared with men. These differences between men and women were also confirmed in a crosssectional study(26) using data from the Spanish National Health Survey (2006) that found that the prevalence of mental health problems was greater in women $(24.6 \%)$ than that in men (14.7\%).

The significant associations and the average values described for the dimensions commitment to studies, absorption, dedication and vigor show similarities with other samples of college students. The research regarding this construct has developed along different lines. Studies have been identified that indicate the relationship between the components of commitment and academic well-being; thus, several studies ${ }^{(13,19-20)}$ show the positive influence of academic commitment on selfefficacy in college students. Variables such as perceived emotional intelligence, general self-efficacy ${ }^{(22)}$ or the influence of burnout syndrome and satisfaction with studies $^{(21)}$ are other areas of interest where the concept of academic commitment is gaining appreciation. It is likely that the study of this construct as the opposite of burnout syndrome is the most developed research area; thus, scales of study engagement are negatively correlated with exhaustion and cynicism and positively correlated with professional efficacy ${ }^{(27)}$, which can be understood as a strategy for controlling stress and therefore positively influencing psychological distress.

In the present study, the women presented higher values for the absorption and dedication variables than men. These results have been analyzed and confirmed by other studies ${ }^{(28)}$ that found significant differences in the dimensions of engagement with regard to sex, showing that women are more effective, vigorous and absorbed in their work as students and more dedicated to their studies than males.

Significant associations between academic engagement and psychological distress have been found, particularly in students who score low in vigor and present higher levels of psychological distress. The regression analysis showed that absorption, dedication and psychological distress (GHQ-12) explain $57.8 \%$ of the variance in vigor, which means that as absorption and dedication decrease and psychological distress gets worse, students' self-perceived vigor also gets

\section{REFERENCES}

1. Organización Mundial de la Salud (OMS). Constitución de la Organización Mundial de la Salud. Ginebra; 1948 worse. Similarly, other studies ${ }^{(9)}$ have associated psychological state with motivation and found that $32.1 \%$ of students had mental health problems and that the lack of interest or motivation had a negative effect on mental health. More recent research ${ }^{(5)}$ reported that confrontation styles and feelings of guilt were highly associated with the GHQ in samples of Japanese nursing students and that additionally, these factors can help to prevent depression. Studies of the relationship between these two variables in college students are scarce, although there is evidence of exposure to different stressors in other populations ${ }^{(15)}$. The need for strategies to promote engagement to guarantee work satisfaction and to reduce stress in nursing professionals has been confirmed ${ }^{(29)}$.

\section{CONCLUSION}

A high level of psychological distress exists among nursing and physical therapy students.

Women had higher psychological discomfort scores and higher absorption and dedication scores compared with men. A projection from the first year would help to identify at-risk subjects who could benefit from specific interventions.

Academic engagement, particularly vigor, is related to student's psychological distress and therefore to energy and mental resilience during the studying process, and the desire to invest effort, time and persistence in the study seems to positively influence psychological distress.

All the dimensions of the student engagement scale (absorption, dedication and vigor) were related to each other. Total concentration on academic work (absorption), enthusiasm (dedication) and lower psychological distress scores predicted high levels of energy and resilience during the studying process (vigor). It is necessary to continue studying this variable to obtain more empirical evidence that supports the importance of this construct in a population that is as susceptible to change as college students are.

In summary, the relationship between the variables studied directs us toward the need to promote study engagement among nursing and physical therapy students as a way to obtain better learning results and alleviate students' psychological distress.

Within the aim of improving the quality of learning and increasing psychological well-being, it would be interesting to study other variables and develop a project aimed at reviewing the workloads established in the curricula of both degrees.
2. World Health Organization (WHO). Regional Office for Europe. Mental health and well-being: why pay attention to this issue during adolescence? [Internet]. Geneva; 2012 [cited 2006 May 28]. Available from: http://www.euro.who.int/_data/assets/pdf_ file/0020/163514/HBSC-Fact-sheet-mental-health-revised.pdf
Psychological distress in health sciences college students and its relationship with academic engagement Liébana-Presa C, Fernández-Martínez ME, Gándara ÁR, Muñoz-Villanueva MC, Vázquez-Casares AM, Rodríguez-Borrego MA 
3. Peterken $\mathrm{Cl}$. The health promoting university: a needs assessment: the potential for change. Portsmouth: University of Portsmouth; 1996.

4. Herrera LM, Rivera MS. Prevalencia de malestar psicológico en estudiantes de enfermería relacionada con factores sociodemográficos, académicos y familiares. Cienc Enferm [Internet]. 2011 [citado 2013 set. 22];17(2):55-64. Disponible en: http://www.scielo.cl/pdf/cienf/v17n2/art_07.pdf

5. Yamashita K, Miwa S, Toshihiro T. Stress and coping styles in Japanese nursing students. Int J Nurs Pract. 2012;18(5):489-96.

6. 6Pulido-Martos M, Augusto-Landa JM, Lopez-Zafra E. Sources of stress in nursing students: a systematic review of quantitative studies. Int Nurs Rev. 2012;59(1):15-25.

7. Lo R. A longitudinal study of perceived level of stress, coping and self-esteem of undergraduate nursing students: an Australian case study. J Adv Nurs. 2002;39(2):119-26.

8. Pourjalia F, Zarnaghashb M. Relationships between assertiveness and the power of saying no with mental health among undergraduate student. Procedia Soc Behav Sci. 2010;9:137-41.

9. Dalir Z, Mazloum SR. Relationship between mental health and interest in field of study in nursing and midwifery students. Life Sci J. 2012:9(3):1916-21.

10. Lotfi MH, Aminian AH, Ghomizadea A, Noorani F. A study on psychological health of first year university students in Iran. Iran J Psychiatr Behav Sci. 2009;3(2):47-51.

11. Uras C, Gennaro R, Aparo UL, Tabolli S. Risk of anxiety and depression in nursing students in Rome, Italy. Ig Sanita Pubbl. 2012;68(4):555-64.

12. Walsh JM, Feeney C, Hussey J, Donnellan C. Sources of stress and psychological morbidity among undergraduate physiotherapy students. Physiotherapy. 2010;96(3):206-12.

13. Salanova MS, Martínez IM, Bresó E, Llorens GS, Grau GR. Bienestar psicológico en estudiantes universitarios: facilitadores y obstaculizadores del desempeño académico. An Psicol [Internet]. 2005 [citado 2013 jul.15];21(1):170-80. Disponible en: http://www.um.es/analesps/v21/v21_1/16-21_1.pdf

14. Goldberg DP, Williams P. Cuestionario de salud general GHQ (General Health Questionnarie). Barcelona: Masson; 1996.

15. Guido LA, Linch GFC, Pitthan LO, Uman J. Estresse, coping e estado de saúde entre enfermeiros hospitalares. Rev Esc Enferm USP [Internet]. 2011 [cited 2013 Dec 06];45(6):14349. Available from: http://www.scielo.br/pdf/reeusp/v45n6/ en_v45n6a22.pdf
16. Salanova M, Schaufeli WB, Llorens S, Peiro JM, Grau RM. Desde el burnout al engagement: ¿una nueva perspectiva? Rev Psicol Trabajo Organ [Internet]. 2000 [2013 jul. 15]:16;11734. Disponible en: http://www.wont.uji.es/wont/downloads/articulos/nacionales/2000SALANOVA02AN.pdf

17. Schaufeli WB, Bakker AB. UWES - Utrecht Work Engagement Scale: preliminary manual. Utrecht/Valéncia: Occupational Health Psychology Unit, Utrecht University; 2003.

18. Schaufeli WB, Salanova M, González-Romá V, Bakker AB. The measurement of burnout and engagement: A confirmatory factor analytic approach. J Happiness Stud. 2002;3(1):71-92.

19. Salanova M, Bresó E, Schaufeli WB. Hacia un modelo espiral de las creencias de eficacia en el estudio del burnout $y$ del engagement. Ansiedad Estrés [Internet]. 2005 [citado 2013 jul. 15]:11(2-3):215-31. Disponible en: http://www.wilmarschaufeli.nl/publications/Schaufeli/243.pdf

20. Salanova M, Cifre E, Grau RM, Llorens S, Martínez IM. Antecedentes de la autoeficacia en profesores y estudiantes universitarios: un modelo causal. Rev Psicol Trabajo Organ [Internet]. 2005 [citado 2013 jul.15]:21(1-2):159-76. Disponible en: http://www.redalyc.org/pdf/2313/231317039010.pdf

21. Oliván Blázquez B, Boira Sarto S, López del Hoyo Y. Estrés y otros factores psicológicos asociados en estudiantes de fisioterapia. Fisioterapia. 2011;33(1):19-24.

22. Durán A, Extremera N, Rey L, Fernández-Berrocal P, Montalbán FM. Predicting academic burnout and engagement in educational settings: assessing the incremental validity of perceived emotional intelligence beyond perceived stress and general self-efficacy. Psicothema. 2006;18 Suppl:158-64.

23. Liébana Presa $C$, Rodríguez Borrego MA, Fernández Martínez ME, Vázquez Casares AM, López Alonso A, Castro González $M P$, et al. Relación entre el estado de salud psicológica inteligencia emocional y burnout en estudiantes de enfermería de la provincia de Leon. Presencia Rev Enferm Salud Mental [Internet]. 2011 [citado 2013 jul.15];7(13). Disponible en: http:// www.index-f.com/presencia/n13/sumario.php

24. Warbah L, Sathiyaseelan M, Vijayakumar C, Vasantharaj B, Russell S, Jacob KS. Psychological distress, personality, and adjustment among nursing students. Nurse Educ Today [Internet]. 2007 [cited 2013 July 15];27(6):597-601. Available from: http://www.sciencedirect.com/science/article/pii/ S0260691706001523

25. Gomathi KG, Ahmed S, Sreedharan J. Psychological health of first-year health professional students in a medical university in the United Arab Emirates. Sultan Qaboos Univ Med J. 2012;12(2):206-13. 
26. Rocha K, Pérez K, Rodríguez-Sanz M, Borrell C, Obiols JE. Prevalencia de problemas de salud mental y su asociación con variables socioeconómicas, de trabajo y salud: resultados de la Encuesta Nacional de Salud de España. Psicothema. 2010;22(3):389-95.

27. Manzano G. Burnout y engagement en un colectivo pre-profesional estudiantes universitarios. Bol Psicol. 2002;74(1):79-102.
28. Martínez IM, Salanova MS. Niveles de burnout y engagement en estudiantes universitarios: relación con el desempeño y desarrollo profesional. Rev Educ. 2003;(330):361-84.

29. Jenaro C, Flores N, Orgaz MB, Cruz M. Vigour and dedication in nursing professionals: Towards a better understanding of work engagement. J Adv Nurs. 2011;67(4):865-75.

\section{Acknowledgments}

A Ana López and Mạ Paz Castro for their contribution. 